\title{
MENINGKATKAN KEMAMPUAN SISWA KELAS VI DALAM MENULIS PUISI BEBAS DENGAN METODE "CONFERENCE WRITING” DI SDN KESAMBEN I KECAMATAN PLUMPANG TUBAN TAHUN PELAJARAN 2014/2015
}

\author{
Lilik Nuka Anik \\ SDN Kesamben I Kecamatan Plumpang Tuban \\ e-mail: liliknuka@gmail.com
}

\begin{abstract}
Abstrak: Tujuan penelitian tindakan kelas ini adalah untuk mendeskripsikan: (1) penerapan metode conference writing dapat meningkatkan kemampuan siswa kelas VI dalam menulis puisi bebas di SDN Kesamben I Plumpang Tuban pada semester II tahun pelajaran 2014/2015. (2) Meningkatkan kemampuan siswa kelas VI dalam menulis puisi bebas dengan menerapkan metode conference writing di SDN Kesamben I Plumpang Tuban pada semester II tahun pelajaran 2014/2015. Desain penelitian ini berbentuk penelitian tindakan kelas. Dalam pelaksanaan penelitian ini dibagi menjadi dua siklus perencanaan, tindakan, observasi, dan refleksi. Sebagai subjek penelitian adalah siswa kelas VI di SDN Kesamben I Plumpang Tuban tahun pelajaran 2014/2015 sebanyak 14 siswa, terdiri dari 8 siswa laki-laki dan 6 siswa perempuan. Analisis data secara deskriptif kualitatif dengan menggunakan persentase dan rata-rata. Kesimpulan hasil penelitian adalah sebagai berikut. (1) Pembelajaran dengan menerapkan metode conference writing dapat meningkatkan kemampuan siswa kelas VI dalam menulis puisi bebas di SDN Kesamben I Kecamatan Plumpang Tuban semester II tahun pelajaran 2014/2015. (2) Kemampuan siswa kelas VI dalam menulis puisi bebas sebelum diterapkan metode conference writing mencapai nilai rata-rata 56,75 (kategori kurang) dengan ketuntasan belajar klasikal yaitu 29\%. Pada siklus I mencapai nilai rata-rata 70,36 (kategori baik) dengan ketuntasan belajar klasikal 65\% (tidak tuntas), dan pada siklus II meningkat nilai rata-rata yaitu 80,86 dengan ketuntasan belajar klasikal 86\%. Peningkatan kemampuan siswa dalam menulis puisi bebas dari siklus I ke siklus II sebesar 10,50.
\end{abstract}

Kata kunci: kemampuan, menulis puisi, metode conference writing

Abstract: The classroom action research aims was to describe: (1) the application of the method of writing conferencing can enhance students' skills in writing essay free verse of VI grade in SDN Kesamben I Plumpang Tuban in the second semester of the school year 2014/2015. (2) Increase the ability of students of VI grade in writing free verse by applying the method of writing conference in SDN Kesamben I Plumpang Tuban in the second semester of the school year 2014/2015. This study design was a Classroom Action Research. In the execution of this study were divided into two cycles of planning, action, observation, and reflection. As research subjects are students of VI grade in SDN Kesamben I Plumpang Tuban school year 2014/2015 was 14 students, consisting of boys were 8 children and women students as many as 6 children. Qualitative descriptive analysis of the data by using percentage and average. Conclusion The results of the study are: (1) learning by applying the method of writing conferencing can enhance the ability of students VI grade in essay writing free verse in SDN Kesamben I Plumpang Tuban school year 2014/2015. (2) There was an increase in the ability of students of VI grade in SDN Kesamben I Plumpang Tuban school year 2014/2015 in essay writing free verse by applying the method of writing conference. Learning before using the method of writing conference with an average value of 56,71 with classical mastery learning which is 29\%. In the first cycle categorized as good with an average value of 70.36 with classical learning completeness $65 \%$, and the second cycle increased the average value is 80,86 to classical learning completeness $86 \%$. Improving the ability of essay writing free verse from the first cycle to the second cycle to achieve improved average value that is equal to 10,50.

Keywords: ability, writing free verse, method of writing conferencing 


\section{PENDAHULUAN}

Bahasa memiliki peran sentral dalam perkembangan intelektual, sosial, dan emosional peserta didik dan merupakan penunjang keberhasilan dalam mempelajari semua bidang studi. Pembelajaran bahasa diharapkan membantu peserta didik mengenal dirinya, budayanya, dan budaya orang lain, mengemukakan gagasan dan perasaan, berpartisipasi dalam masyarakat yang menggunakan bahasa tersebut, dan menemukan serta menggunakan kemampuan analitis dan imajinatif yang ada dalam dirinya (Depdiknas, 2006).

Pada hakikatnya belajar bahasa adalah belajar komunikasi. Oleh karena itu, pembelajaran bahasa Indonesia diarahkan untuk meningkatkan kemampuan menulis siswa dalam berkomunikasi dalam bahasa Indonesia dengan baik dan benar, baik secara lisan maupun secara tertulis, serta menumbuhkan apresiasi terhadap hasil karya kesastraan manusia Indonesia (Depdiknas, 2006: 2).

Keterampilan menulis merupakan salah satu keterampilan berbahasa yang perlu diajarkan pada siswa secara terpadu dengan keterampilan berbahasa yang lain. Namun pada kenyataannya 71\% dari jumlah 14 siswa Kelas VI di SDN Kesamben I Plumpang Tuban kemampuan dan keterampilan berbahasa dalam hal ini tentang menulis puisi masih rendah, karena mereka belum menguasai dan mengalami kesulitan menemukan ide, kesulitan menentukan/memilih katakata maupun kalimat yang akan dituangkan dalam puisi, dan siswa sering menulis kata-kata dalam puisi yang kurang padu.

Faktor penyebab kesulitan siswa kelas VI dalam belajar bahasa Indonesia khususnya tentang menulis puisi antara lain: (1) guru dalam melaksanakan proses pembelajaran bahasa Indonesia (menulis puisi) terbiasa dan terpaku menggunakan buku teks dan penunjang pelajaran sehingga siswa hanya sekadar mencontoh atau menyalin materi yang ada di buku teks tersebut, serta guru kurang memotivasi siswa dalam belajar mengeksplorasikan gagasan (ide) baik dari pengalaman pribadi maupun dari sumber belajar yang lain. (2) Guru dalam melaksanakan proses pembelajaran menulis puisi masih kurang dan sekadar memberikan tugas kepada siswa sehingga kurang memperhatikan kelemahan yang terjadi pada proses pembelajaran menulis tersebut. (3) Rendahnya kemampuan siswa dalam bidang menulis karena kurangnya latihan atau belajar mengungkapkan gagasan/ide dan pengalaman yang dituangkan dalam kegiatan menulis puisi. (4) Penguasaan dan pemahaman siswa terhadap kosakata dan kalimat dalam penulisan puisi masih kurang.

Berdasarkan latar belakang di atas, dalam proses pembelajaran bahasa Indonesia di Kelas VI SDN Kesamben I Kecamatan Plumpang Tuban guru ingin memperbaiki strategi dan metode pembelajaran menulis yang lebih inovatif sesuai dengan perkembangan zaman untuk peningkatan kualitas dan kuantitas keterampilan berbahasa Indonesia melalui pembelajaran keterampilan menulis dengan mengadakan penelitian tindakan kelas membahas judul tentang "Meningkatkan Kemampuan Siswa Kelas VI dalam Menulis Puisi Bebas dengan Metode "Conference Writing” di SDN Kesamben I Kecamatan Plumpang Tuban pada Semester II Tahun Pelajaran 2014/ 2015.”

Berdasarkan uraian pada latar belakang dan judul penelitian di atas, peneliti merumuskan masalah sebagai berikut: (1) Apakah dengan metode conference writing dapat meningkatkan kemampuan siswa Kelas VI dalam menulis puisi bebas di SDN Kesamben I Kecamatan Plumpang Tuban pada semester II tahun pelajaran 2014/ 2015 ? (2) Bagaimana penerapan metode confer- 
ence writing dapat meningkatkan kemampuan siswa kelas VI dalam menulis puisi bebas di SDN Kesamben I Kecamatan Plumpang Tuban pada semester II tahun pelajaran 2014/2015?

Adapun tujuan penelitian tindakan kelas ini yaitu: (1) ingin mendeskripsikan penerapan metode conference writing dapat meningkatkan kemampuan siswa Kelas VI dalam menulis puisi bebas di SDN Kesamben I Kecamatan Plumpang Tuban pada semester II tahun pelajaran 2014/2015. (2) Meningkatkan kemampuan siswa Kelas VI dalam menulis puisi bebas dengan menerapkan metode conference writing di SDN Kesamben I Kecamatan Plumpang Tuban pada semester II tahun pelajaran 2014/2015.

\section{TINJAUAN PUSTAKA}

Crimmon (dalam Elina Syarif, dkk., 2012:5) berpendapat bahwa menulis adalah kerja keras, tetapi juga merupakan kesempatan untuk menyampaikan sesuatu tentang diri sendiri mengomunikasikan gagasan kepada orang lain, bahkan dapat mempelajari sesuatu yang belum diketahui. Lebih jauh Rusyana (1984) memberikan batasan bahwa kemampuan menulis atau mengarang adalah kemampuan menggunakan pola-pola bahasa dalam tampilan tertulis untuk mengungkapkan gagasan atau pesan. Kemampuan menulis mencakup berbagai kemampuan, seperti kemampuan menguasai gagasan yang dikemukakan, kemampuan menggunakan unsur-unsur bahasa, kemampuan menggunakan gaya, dan kemampuan menggunakan ejaan serta tanda baca (Elina Syarif, dkk., 2012:5).

Menulis puisi merupakan bentuk keterampilan menulis deskripsi yaitu pemaparan atau penggambaran dengan kata-kata suatu benda, tempat, suasana atau keadaan. Seorang penulis deskripsi mengharapkan pembacanya, melalui tulisannya, dapat 'melihat' apa yang dilihatnya, dapat 'mendengar' apa yang didengarnya, 'merasakan' apa yang dirasakannya, serta sampai kepada 'kesimpulan' yang sama dengannya. Dari sini dapat disimpulkan bahwa deskripsi merupakan hasil dari observasi melalui pancaindra, yang disampaikan dengan kata-kata (Marahimin dalam Elina Syarif, dkk., 2012:8).

Dalam pembelajaran bahasa Indonesia (menulis puisi), banyak strategi pembelajaran yang tersedia selain metode diskusi dan penugasan. Guru dapat lebih efektif dalam proses pembelajaran menulis puisi jika menerapkan metode konstruktivistik dan kontekstual yaitu metode conference writing. Penerapan metode conference writing didasarkan pada teori belajar kognitif yang menekankan pada pembelajaran kooperatif, pembelajaran generatif strategi bertanya, inkuiri, atau menemukan dan keterampilan metakognitif lainnya. Di mana implementasinya ke dalam pembelajaran menitikberatkan pada siswa untuk melakukan proses mental atau kerja otak atas informasi itu agar informasi tersebut masuk ke dalam pemahaman mereka (konstruktivitik), yang dimulai dari masalah (sering muncul dari siswa sendiri) dan selanjutnya membantu siswa menyelesaikan dan menemukan langkah-langkah pemecahan masalah tersebut. Di samping itu proses pembelajaran bersifat kontekstual yaitu menghubungkan materi pelajaran dengan situasi dunia nyata dan pembelajaran yang memotivasi siswa agar menghubungkan pengetahuan dan terapannya dengan kehidupan sehari-hari sebagai anggota keluarga dan masyarakat (Elina Syarif, dkk., 2012:17).

\section{METODE}

Penelitian ini didesain dalam bentuk penelitian tindakan kelas (PTK). Definisi PTK adalah 
suatu bentuk penelitian yang bersifat praktis dengan tindakan-tindakan yang dilakukan di kelas dan bertujuan untuk memperbaiki dan meningkatkan praktik pembelajaran yang ada (Kasihani, 2008:1).

PTK ini dilaksanakan secara berdaur (dari siklus ke siklus berikutnya). Di mana setiap siklusnya dilaksanakan dengan 4 tahapan terdiri dari perencanaan, pelaksanaan tindakan, observasi, dan refleksi (Arikunto, dkk., 2007:105).

Dalam pelaksanaan PTK guru sekaligus dapat meneliti sendiri (mendeskripsikan situasi) terhadap kegiatannya (proses pembelajaran) yang dilakukan di kelasnya sendiri. Peneliti bertindak sebagai instrumen penelitian dan dengan melibatkan siswanya melalui tindakan-tindakan direncanakan, dilaksanakan dan dievaluasi. Kegiatan PTK ini tanpa mengganggu pembelajaran yang lain dan tidak akan membebani pekerjaan guru dalam melaksanakan tugas sehari-hari. PTK dapat dilakukan secara integrasi dengan kegiatan sehari hari.

Lokasi penelitian adalah SDN Kesamben I Kecamatan Plumpang Tuban dan waktu pelaksanaan penelitian tindakan kelas ini pada semester II tahun pelajaran 2014/2015 yaitu pada bulan Februari 2015. Sesuai jadwal pelajaran bahasa Indonesia di Kelas VI SDN Kesamben I Kecamatan Plumpang Tuban. Pelaksanaan siklus I (pertemuan ke-1 (hari Selasa, 10 Februari 2015 dan pertemuan ke-2 hari Rabu, 11 Februari 2015); Pelaksanaan siklus II (pertemuan ke-1 hari Selasa, 17 Februari 2015 dan pertemuan ke-2 hari Rabu 18 Februari 2015).

Subjek dalam penelitian ini adalah siswa Kelas VI SDN Kesamben I Kecamatan Plumpang Tuban dengan jumlah siswa 14 anak, terdiri dari 8 siswa laki-laki dan 6 siswa perempuan.

Alat pengumpulan data penelitian ini meliputi: (1) lembar observasi, (2) dokumentasi berupa RPP, hasil observasi, hasil tugas siswa, hasil penilaian, dan foto-foto kegiatan selama proses pembelajaran.

Analisis data menggunakan deskriptif kualitatif dan penghitungan nilai rata-rata (mean) dan persentase (\%) untuk menentukan ketuntasan belajar siswa baik secara individual maupun secara klasikal yang didasarkan pada kriteria ketuntasan belajar minimal (KKM) mata pelajaran Bahasa Indonesia yang ditetapkan dalam kurikulum SDN Kesamben I Kecamatan Plumpang Tuban.

\section{HASIL PENELITIAN DAN PEMBAHASAN}

Peneliti dalam melaksanakan PTK ini dengan menerapkan 2 (dua) siklus. Prosedur kegiatan Penelitian Tindakan Kelas ini sebagai berikut: (1) Pada siklus I diawali dengan tahap perencanaan antara lain: (a) menyiapkan rencana pelaksanaan pembelajaran (RPP) mata pelajaran bahasa Indonesia. (b) Menyiapkan LKS sebagai bahan pembelajaran. (c) Menyediakan alat/media pembelajaran. (d) Menyiapkan instrumeninstrumen penelitian, berupa format pengamatan dan alat penilaian (tes). (2) Pelaksanaan tindakan yaitu guru melaksanakan proses pembelajaran sesuai dengan RPP sekaligus bertindak sebagai peneliti. (3) Observasi dilakukan pengamatan terhadap tingkah laku siswa selama proses pembelajaran berlangsung difokuskan pada kemampuan siswa dalam keterampilan menulis puisi bebas, dan kemampuan guru dalam melaksanakan pembelajaran dengan menerapkan metode conference writing. (4) Refleksi. Dari keseluruhan data yang telah diperoleh, peneliti melakukan refleksi, apakah hasil dari pelaksanaan tindakan yang dilakukan berhasil atau tidak sesuai dengan tujuan yang diharapkan. Hasil refleksi data yang dilaksanakan pada siklus I akan digunakan sebagai acuan untuk merencanakan siklus berikutnya. Pada siklus II tahapan 
tindakan yang dilakukan peneliti sama dengan siklus I yang tujuannya untuk memecahkan masalah, memperbaiki kelemahan yang sebelumnya timbul pada siklus I, sehingga pada siklus II ini terjadi peningkatan derajat keberhasilan dalam mencapai tujuan pembelajaran yaitu siswa mampu menulis puisi bebas.

Hasil penelitian dapat dikemukakan sebagai berikut.

1. Pada kegiatan awal (para tindakan) pembelajaran menulis puisi bebas masih menerapkan metode pemberian tugas. Pada pembelajaran Bahasa Indonesia khususnya tentang menulis karangan puisi bebas peneliti mengamati aktivitas dan perilaku siswa, serta mengadakan penilaian terhadap kemampuan siswa dalam menulis karangan puisi bebas. Data yang diperoleh dari pengamatan dan pelaksanaan penilaian yang dilakukan peneliti pada pra tindakan menunjukkan rata-rata aktivitas belajar siswa cukup baik (79\%), dan kemampuan siswa kelas VI SDN Kesamben I Kecamatan Plumpang Tuban dalam belajar menulis karangan puisi bebas mencapai nilai ratarata 56,71. Dengan ketuntasan belajar secara klasikal mencapai 29\%. Untuk mengatasi permasalahan yang ada guru sekaligus peneliti menyusun instrumen tindakan yang terangkum dalam dua siklus.

2. Pada siklus I diterapkan metode conference writing dalam pembelajaran menulis karangan puisi. Pelaksanaan siklus I diikuti oleh 14 siswa kelas VI dalam belajar menulis puisi bebas mereka masih mengalami permasalahan. Berdasarkan hasil pengamatan keaktifan siswa selama pembelajaran menulis karangan puisi bebas dengan menerapkan metode conference writing menunjukkan 50\% siswa aktif. Sedangkan dari hasil penilaian kemampuan siswa dalam menulis karangan puisi bebas menunjukkan nilai rata-rata 70,36 (cukup baik), dan ketuntasan belajar secara klasikal mencapai 65\%. Sehingga hasil penelitian tindakan kelas pada siklus I ini dinyatakan belum dapat mencapai tujuan pembelajaran karena hasil yang didapat secara klasikal belum sesuai dengan kriteria ketuntasan belajar minimal (KKM) yang ditetapkan oleh sekolah sebesar $85 \%$.

Pada siklus I pembelajaran dengan menerapkan metode conference writing ini secara klasikal terjadi peningkatan nilai rata-rata hasil belajar (kemampuan) siswa dalam menulis puisi bebas dan persentase ketuntasan belajar jika dibandingkan dengan hasil pembelajaran sebelumnya dengan menggunakan metode pemberian tugas. Peningkatan hasil penelitian siklus I ini dapat dilihat pada grafik berikut.

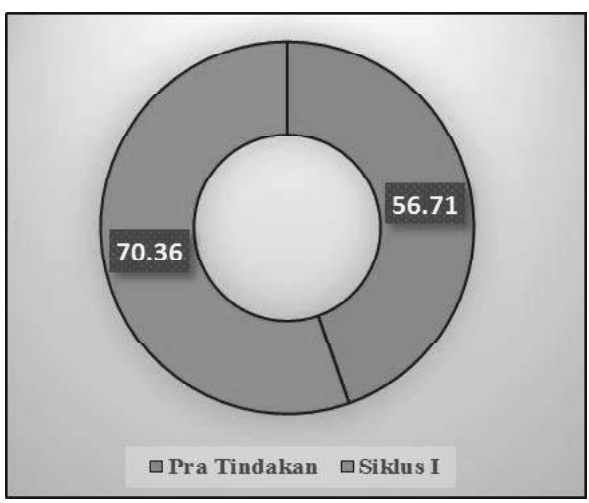

Grafik 1 Perbandingan Nilai Rata-Rata Kemampuan Siswa dalam Menulis Puisi Bebas pada Kegiatan Pra-tindakan (Awal) dan Siklus I

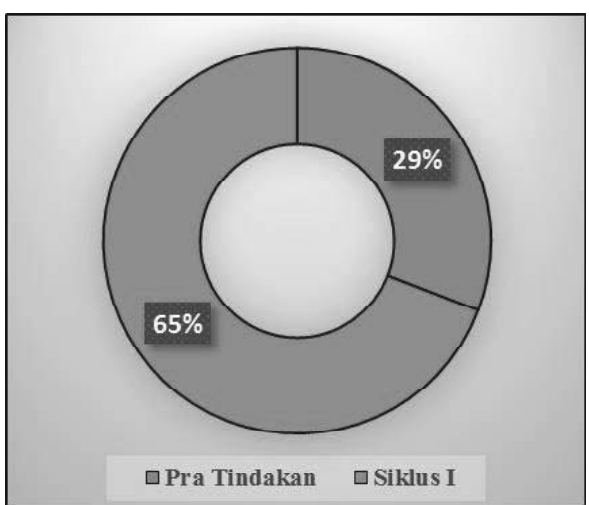

Grafik 2 Perbandingan Ketuntasan Belajar Klasikal pada Kegiatan Pra-tindakan dan Siklus I 
Selanjutnya sebagai refleksi dari hasil pelaksanaan penelitian siklus I ternyata belum dapat mencapai tujuan pembelajaran, kemudian guru sebagai peneliti akan memperbaiki proses pembelajaran menulis karangan puisi bebas dengan menerapkan metode conference writing dengan melanjutkan penelitian tindakan kelas pada siklus II yang menekankan pada kegiatan antara lain secara bersama siswa menggali dan memperluas pengalamannya. melalui membaca buku sastra (berisi puisi), berdiskusi, mengidentifikasi pengalaman, memproses, mengevaluasi, menyeleksi, dan menggabungkan/menghubung-hubungkan semua informasi untuk bahan menulis karangan puisi bebas, menyusun/menentukan ide-ide pokok untuk menyusun kerangka tulisan (outline), dan selanjutnya mengembangkan menjadi karangan puisi bebas dalam bentuk buram (draft), mengadakan pengecekan ulang terhadap hasil karangan meliputi bentuk susunan tulisan, konsistensi alur pikiran (penalaran), penggunaan bahasa dan ejaan, dan mengedit keseluruhan hasil karangan puisi bebas yang telah dibuat.

3. Pada siklus II pembelajaran dengan menerapkan metode conference writing sebagai kelanjutan dari pelaksanaan pembelajaran siklus I yang belum dapat mencapai tujuan pembelajaran yang diharapkan. Adapun hasil penelitian ini dikemukakan bahwa berdasarkan pengamatan terhadap tingkat keaktifan siswa selama pembelajaran menulis karangan puisi bebas dengan menerapkan metode conference writing pada siklus II ini menunjukkan 68\% (aktif). Selanjutnya mengenai hasil penilaian terhadap kemampuan siswa dalam menulis karangan puisi bebas pada penelitian siklus II ini mencapai nilai rata-rata yaitu 80,86 (baik), dengan ketuntasan belajar secara klasikal menunjukkan $86 \%$, sehingga dalam pelaksanaan penelitian siklus II ini pembelajaran menulis puisi bebas dengan menerapkan metode conference writing oleh siswa kelas VI SDN Kesamben I Kecamatan Plumpang Tuban semester II tahun pelajaran 2014/2015 telah dapat mencapai tujuan pembelajaran karena hasil belajar yang dicapai siswa di atas kriteria ketuntasan belajar minimal yang ditetapkan dalam kurikulum SD.

Sebagai ilustrasi keberhasilan (peningkatan) hasil belajar berupa kemampuan siswa kelas VI SDN Kesamben I Kecamatan Plumpang Tuban dalam menulis puisi bebas melalui penelitian tindakan kelas dari siklus I ke siklus II dapat dilihat pada Grafik 3 dan Grafik 4 sebagai berikut.

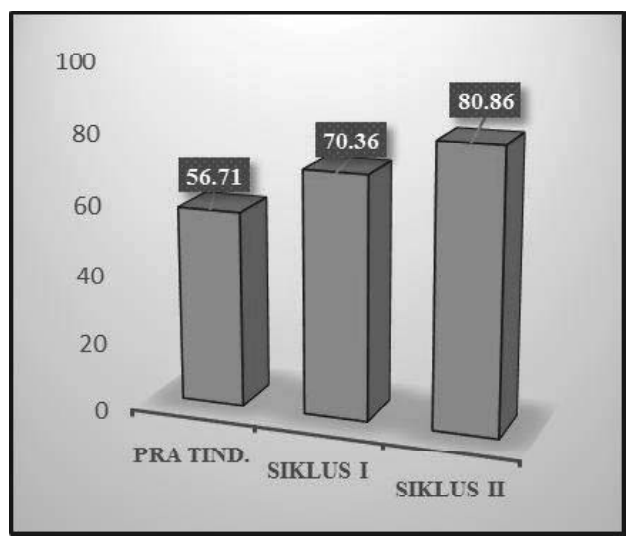

Grafik 3 Perbandingan Nilai Rata-Rata Kemampuan Siswa dalam Menulis Puisi Bebas pada Kegiatan Pratindakan (Awal), Siklus I, dan Siklus II

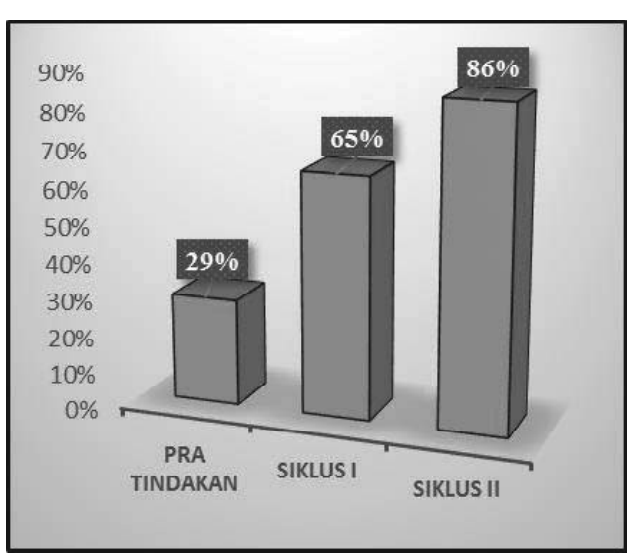

Grafik 4 Perbandingan Ketuntasan Belajar Klasikal pada Kegiatan Pra-tindakan, Siklus I, dan Siklus II 
Dengan demikian berdasarkan hasil penelitian tindakan kelas yang diterapkan dua siklus, maka pembelajaran bahasa Indonesia dengan menerapkan metode conference writing dapat meningkatkan kemampuan siswa kelas VI SDN Kesamben I Kecamatan Plumpang Tuban dalam menulis puisi bebas.

\section{SIMPULAN DAN SARAN}

Berdasarkan pembahasan di atas maka dapat ditarik kesimpulan: (1) Pembelajaran dengan menerapkan metode conference writing dapat meningkatkan kemampuan siswa Kelas VI dalam menulis puisi bebas di SDN Kesamben I Kecamatan Plumpang Tuban semester II tahun pelajaran 2014/2015. (2) Kemampuan siswa kelas VI dalam menulis puisi bebas sebelum diterapkan metode conference writing mencapai nilai ratarata 56,75 (kategori kurang) dengan ketuntasan belajar klasikal yaitu 29\%. Pada siklus I mencapai nilai rata-rata 70,36 (kategori baik) dengan ketuntasan belajar klasikal 65\% (tidak tuntas), dan pada siklus II meningkat nilai rata-rata yaitu 80,86 dengan ketuntasan belajar klasikal $86 \%$. Peningkatan kemampuan siswa dalam menulis puisi bebas dari siklus I ke siklus II sebesar 10,50 .

Terkait dengan kesimpulan hasil penelitian tersebut peneliti mengemukakan saran-saran/ rekomendasi sebagai berikut.

1. Diharapkan guru dalam melaksanakan pembelajaran agar memberikan layanan bimbingan dan motivasi terhadap siswa agar prestasi belajar yang dicapai lebih baik.

2. Dalam mengembangkan kemampuan siswa dalam belajar menulis puisi bebas hendaknya guru menerapkan metode conference writing.
3. Guru dalam melaksanakan proses pembelajaran hendaknya memberikan kesempatan seluas-luasnya kepada siswa untuk mengembangkan kemampuan, ide-ide, dan berpikir kreatif.

\section{DAFTAR PUSTAKA}

Arikunto, Suharsimi. 2007. Prosedur Penelitian Suatu Pendekatan Praktik. Jakarta: Rineka Cipta

Asron dkk. 2009. Dari Narasi hingga Argumentasi. Jakarta: Erlangga.

Departemen Pendidikan Nasional. 2006. Kurikulum 2006. Jakarta: Depdiknas.

Elina Syarif, Zulkarnaini, dan Sumarmo. 2012. Pembelajaran Menulis. Jakarta: Kemendikbud.

Djamarah, Bahri, Syaful dan Aswan, Z. 2012. Stategi Belajar Mengajar. Jakarta: Rineka Cipta.

Gugus, Mardini. 2009. Peningkatan Keterampilan menulis Puisi Menggunakan Metode Conference Writing. Jurnal Gentengkali. No. 3 Tahun III. Surabaya: Proyek PPM SLTP Jatim.

Kasihani, Kasballah. 2008 Penelitian Tindakan Kelas. Malang: UM.

Moeliono, M. Anton. 2013. Tata Bahasa Baku Bahasa Indonesia. Jakarta: Kemendikbud. Nurgiantoro, Burhan. 2015. Sastra Anak (Pengantar pemahaman Dunia Anak). Yogyakarta: UGM Press.

Suyuti, Sumitro A. 2008. Apresiasi Prosa Fiksi. Jakarta: Kemendiknas.

Syafi'i, Imam. 2011. Retorika dalam Menulis. Jakarta: P2LPTK.

Tarigan, Henry Guntur. 2008. Menulis Sebagai Salah Satu Keterampilan Berbahasa. Bandung: Angkasa. 
Education and Human Development Journal, Vol. 3, No. 1, April 2018 